\title{
STUDI PEMANFAATAN ABU SEKAM PADI SEBAGAI PENGISI DALAM PEMBUATAN BETON
}

\author{
Ir. Marthen Luther Paembonan, MT \\ Staf Pengajar Program Studi Teknik Sipil, Fakultas Teknik, UKI Toraja
}

\begin{abstract}
ABSTRAK
Beton adalah campuran dari semen, agregat, air dan bahan tambahan dalam perbandingan tertentu. B eton merupakan bahan bangunan yang umumnya dipakai dalam pembangunan fisik karena mudah dibentuk dan biaya pemeliharaan yang relatif murah dibandingkan dengan material lainnya.

Perkembangan ilmu pengetahuan di bidang teknologi beton memungkinkan penggunaan limbah menjadi bahan pembentuk beton, sehingga di satu sisi penggunaan bahan alam yang merusak lingkungan dapat diatasi dan di sisi lain bahan limbah dimanfaatkan seoptimal mungkin untuk bahan pembentuk beton. Abu sekam padi merupakan hasil dari pembakaran limbah pengolahan padi. Penelitian tentang Abu Sekam Padi sebagai pengisi pada beton ini dilakukan untuk mengetahui pengaruh penambahan abu sekam padi terhadap kuat tekan beton tanpa mengurangi semen. Dan dari hasil pengujian menunjukkan bahwa penambahan abu sekam padi 10 $\%$ dapat meningkatkan kuat tekan beton dengan kuat rencana 20 Mpa pada umur 28 hari. Selain itu Hasil pengujian kuat tekan juga menunjukkan bahwa kuat tekan beton normal pada umur 28 hari yaitu 20,2 Mpa dan untuk penambahan abu sekam padi pada umur 28 hari yaitu 21,5 Mpa dengan kata lain terjadi peningkatan kuat tekan sebesar 3,1\% dari beton normal.

Berdasarkan hasil penelitian tersebut menunjukkan bahwa pemanfaatan abu sekam padi sebagai pengisi dapat digunakan dalam pembuatan beton.
\end{abstract}

Kata Kunci : Abu Sekam Padi, Bahan Tambah, Kuat Tekan Beton. 


\section{PENDAHULUAN}

Beton merupakan salah satu bahan konstruksi yang banyak digunakan untuk pembangunan infrastruktur. Secara umum beton merupakan penggabungan dari material - material seperti semen, air dan agregat yang membentuk massa padat.

Makin meningkatnya kebutuhan pembangunan saat ini menyebabkan kebutuhan akan bahan bangunan semakin meningkat pula. Sebagaimana diketahui, kebutuhan masyarakat akan pembangunan tidak pernah surut bahkan selalu meningkat dari tahun ke tahun.

Adapun salah satu permasalahan utama dalam pembanguan di Indonesia adalah tingginya biaya konstruksi bangunan dan lahan. Selama ini berbagai penelitian sudah dilakukan tetapi masih belum ditemukan alternatif teknik konstruksi yang effisien serta penyediaan bahan bangunan dalam jumlah besar dan ekonomis. Hal tersebut dapat memberikan suatu alternatif untuk memanfaatkan limbah-limbah industri yang dibiarkan begitu saja. Limbah industri untuk bahan campuran beton ternyata mampu meningkatkan daya kuat tekan.

Penelitian ini akan mencoba memanfaatkan abu sekam padi sebagai Filler dalam pembuatan beton. Sekam biasanya merupakan bahan buangan yang pembuangannya sering menjadi masalah, sekam biasanya dibakar di tempat terbuka melalui pembakaran secara terkontrol sekam diubah menjadi abu yang dapat menjadi sumber silika dalam bentuk amorphous untuk keperluan berbagai industri. Panas yang dihasilkan dalam pembakaran $( \pm 3000 \mathrm{kcal} / \mathrm{kg})$.

Pembakaran sekam padi memiliki unsur yang bermanfaat untuk peningkatan kekuatan beton, mempunyai sifat pozzolan dan mengandung silika yang sangat menonjol bila unsur ini dicampur dengan semen akan menghasilkan kekuatan yang lebih tinggi.

Tujuan dari penulisan ini adalah : untuk mengetahui pengaruh penggunaan abu sekam padi sebagai pengisi pada campuran beton dan membandingkan kekuatan beton campuran abu sekam dengan beton normal.

\section{METODOLOGI PENELITIAN}

Lokasi Pengambilan Material

Suatu hal yang perluh diperhatikan dalam melakukan penelitian adalah penentuan atau pemilihan lokasi tempat pengambilan sampel ( contoh ) uji. Bahan - bahan campuran dalam penelitian ini tersiri dari agregat halus (pasir), agregat kasar (batu pecah), abu sekam padi (Rice Husk Ash), semen dan air dengan ukuran dan karakteristik sebagai berikut : 
a. Agregat halus ( pasir ) :

Agregat halus yang digunakan adalah agregat halus yang berasal dari sungai Tapparan $\pm 12 \mathrm{~km}$ dari kota makale, Kabupaten Tana Toraja. Lokasi ini dipilih sebagi lokasi pengambilan sampel karena jenis dan jumlah material yang cukup banyak, sarana transportasi ke tempat tersebut sangat memedai.

b. Agregat kasar :

Dalam penelitian ini penulis memilih lokasi pengambilan agregat kasar ( batu pecah ) di PT. Sabar Jaya $\pm 1 \mathrm{~km}$ dari kota Makale, Kabupaten Tana Toraja. Lokasi ini dipilih sebagi lokasi pengambilan sampel karena jenis dan jumlah material yang cukup banyak, sarana transportasi ke tempat tersebut sangat memedai.

a. Abu Sekam Padi ( Rice Husk Ash )

Penulis memilih lokasi pengambilan Abu Sekam Padi dalam penelitian ini di daerah Sangalla' Kabupaten Tana Toraja $\pm 4 \mathrm{~km}$ dari kota Makale Kabupaten Tana Toraja. Lokasi ini dipilih sebagai tempat pengambilan sampel abu sekam padi karena di sekitar lokasi banyak terdapat abu sekam padi hasil dari penggilingan padi, dan saran transportasi ke tempat tersebut memedai.

b. Semen

Semen yang dipakai dalam penelitian ini adalah semen jenis type 1 Tonasa.

c. Air

Dalam penelitian ini penulis menggunakan air dalam campuran benda uji adalah air bersih yang bersumber dari Daerah Air Minum (PDAM) Makale, Kabupaten Tana Toraja.

\section{Penelitian Laboratorium}

Tempat melaksanakan penelitian ini adalah di Laboratorium Dinas Pekerjaan Umum Kabupaten Tana Toraja.

Pemeriksaan bahan harus memenuhi syarat ASTM sebelum dilakukan perancangan mix design. Mix design selesai maka dilanjutkan pada pembuatan beton segar untuk pengujian nilai slump demi mengetahui kekentalan campuran sekaligus pembuatan benda uji. Selanjutnya setelah pembuatan benda uji sudah mulai kering (bisa dikeluarkan dari cetakan) cetakan berbentuk kubus $15 \times 15 \mathrm{~cm}$, maka proses selanjutnya adalah perawatan benda uji dengan merendam benda uji kedalam bak rendaman selam 3, 7, 14 dan 28 hari. Kemudian benda uji diangkat dari bak rendaman untuk dikeringkan sehari sebelum dilakukan pengujian kuat tekan beton. 


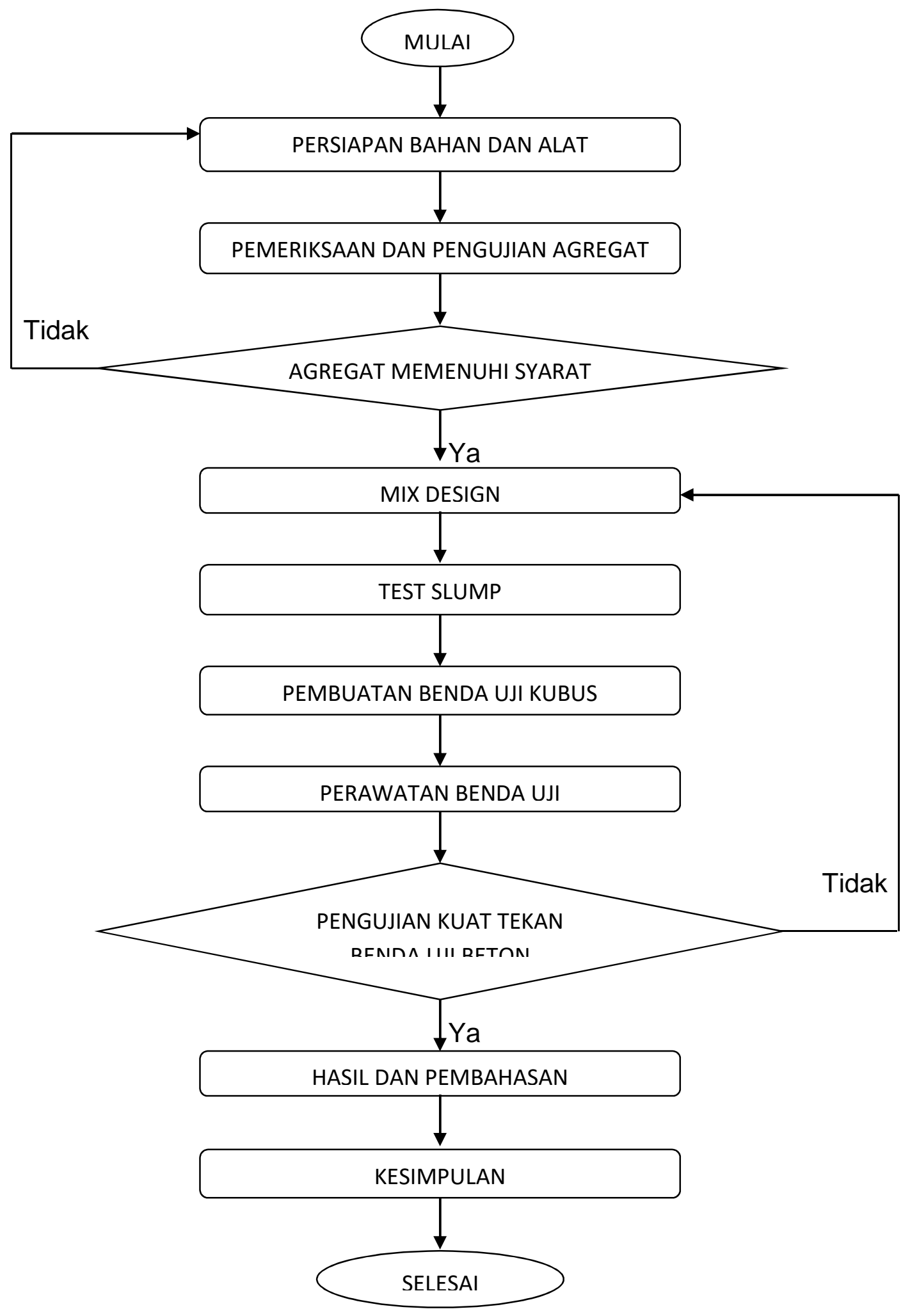

Gambar 1. Bagan Alir Penelitian 


\section{PE MBAHASAN HASIL PENE LITIAN}

\section{Hasil Pemeriksaan Agregat}

Berdasarkan hasil pengujian karakteristik agregat kasar (cipping) diketahui bahwa semua hasil pengujian memenuhi spesifikasi bahan beton menurut standar ASTM.

\section{Penggabungan Agregat}

Grafik 1. Hasil Pemeriksaan Gradasi Agregat Halus Zona I

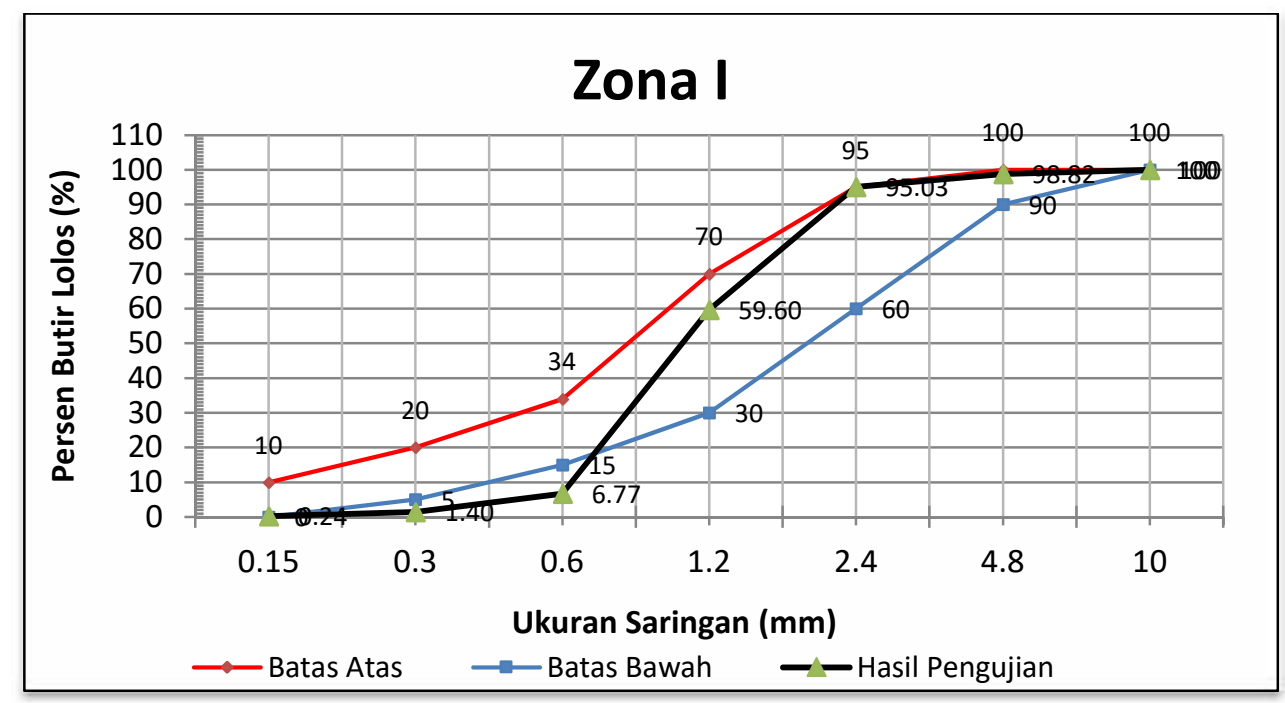

Grafik 2. Hasil Pemeriksaan Gradasi Agregat Halus Zona II

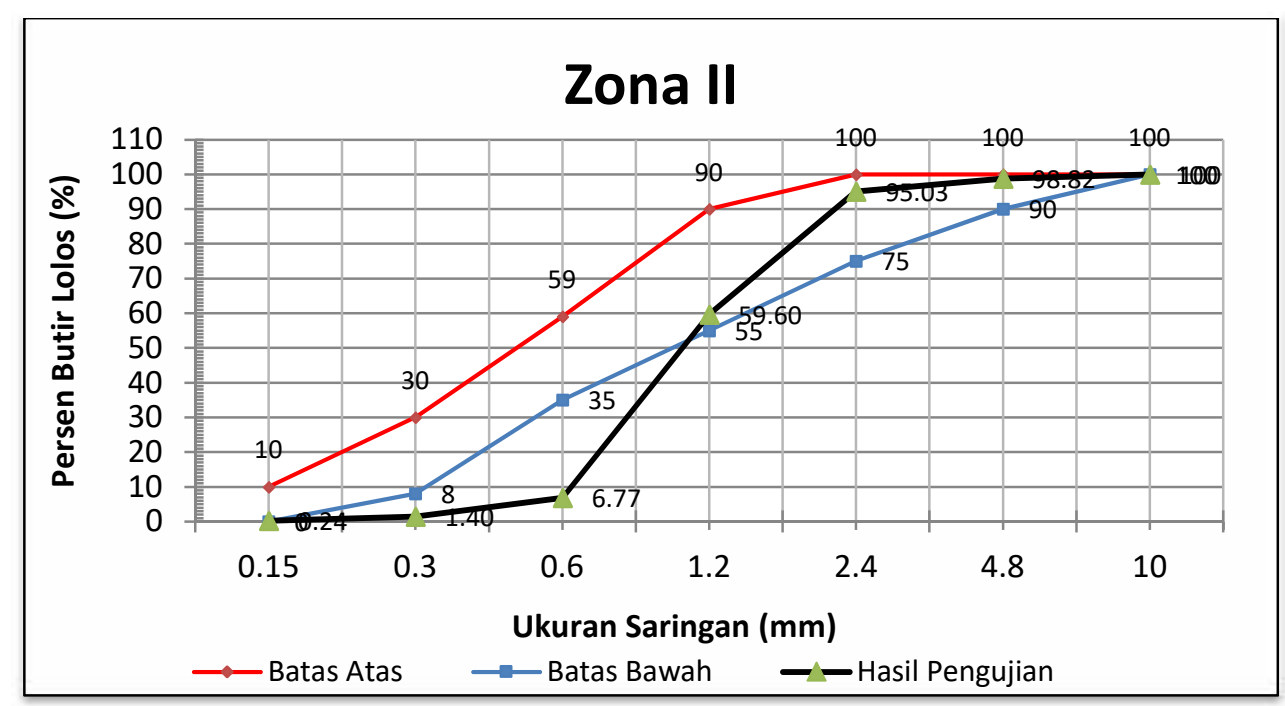

Grafik 3. Hasil Pemeriksaan Gradasi Agregat Halus Zona III 


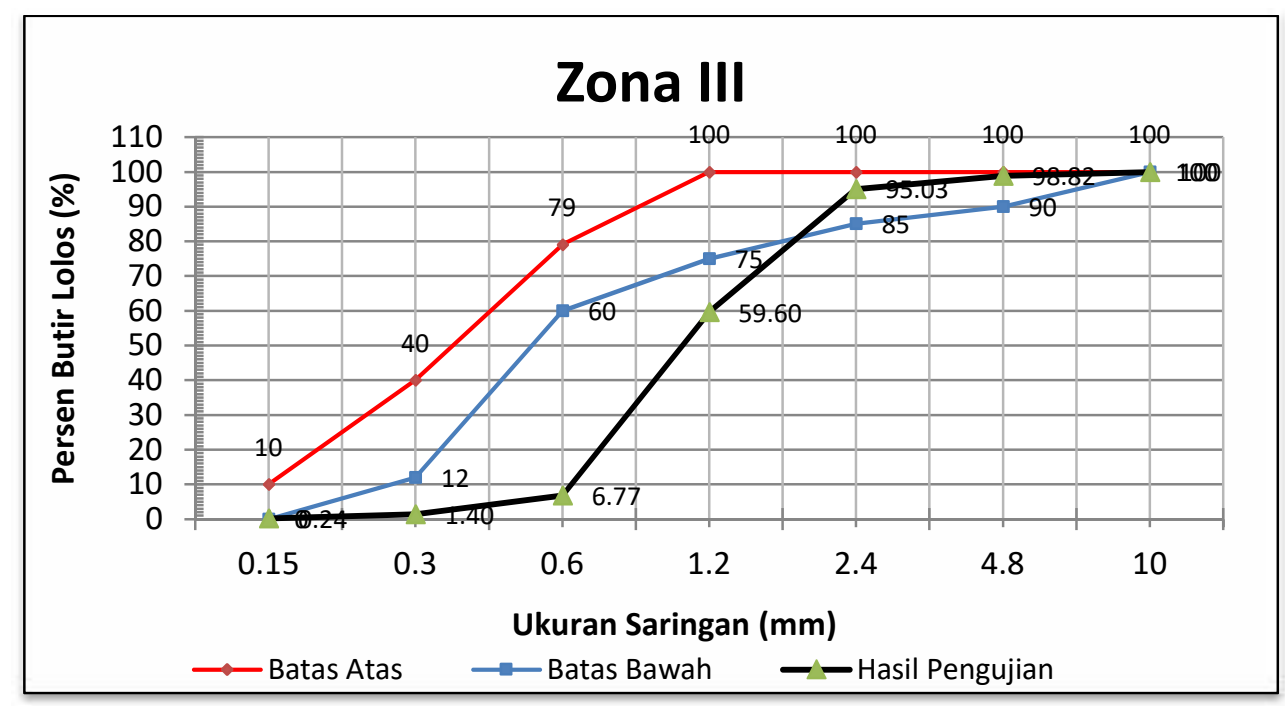

Grafik 4. Hasil Pemeriksaan Gradasi Agregat Halus Zona IV

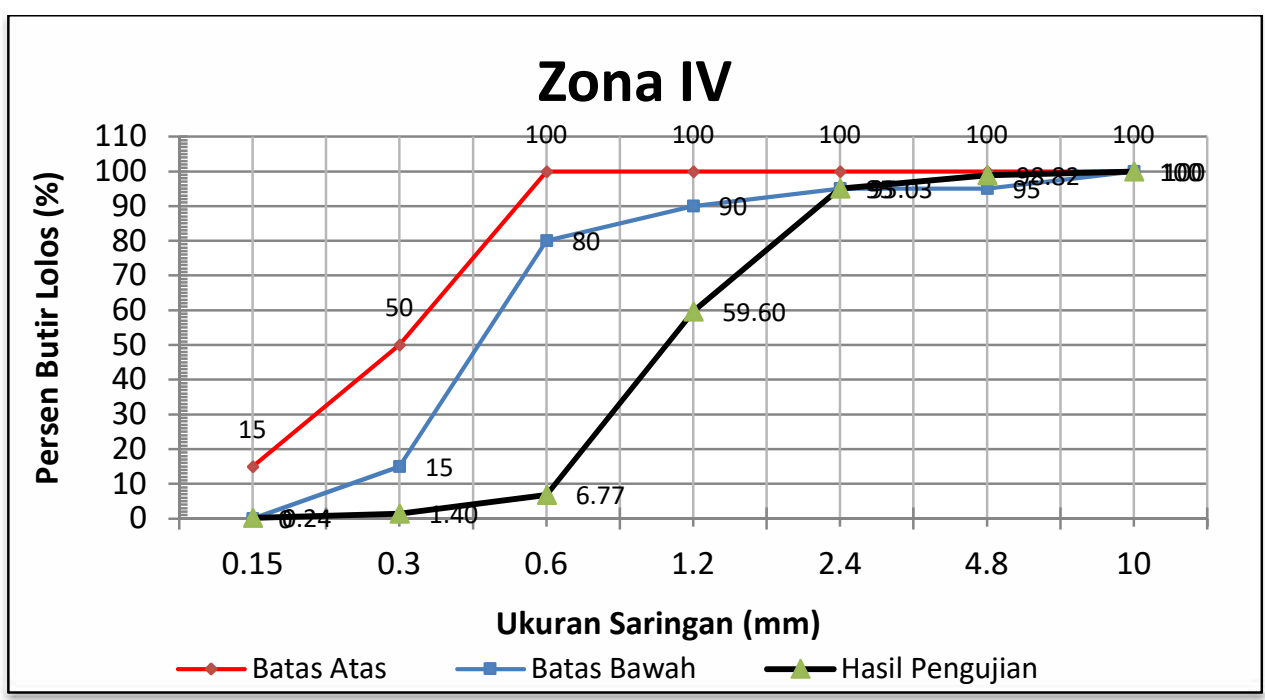

Dari grafik $1 \mathrm{~s} / \mathrm{d} 4$ memperlihatkan bahwa gradasi agregat halus masuk dalam zona II atau merupakan kategori agregat agak kasar, dan sesuai dengan nilai standar yang telah di tentukan oleh SK SNI T-15-1990-03. 
Grafik 5 Hasil Pemeriksaan Gradasi Agregat Kasar

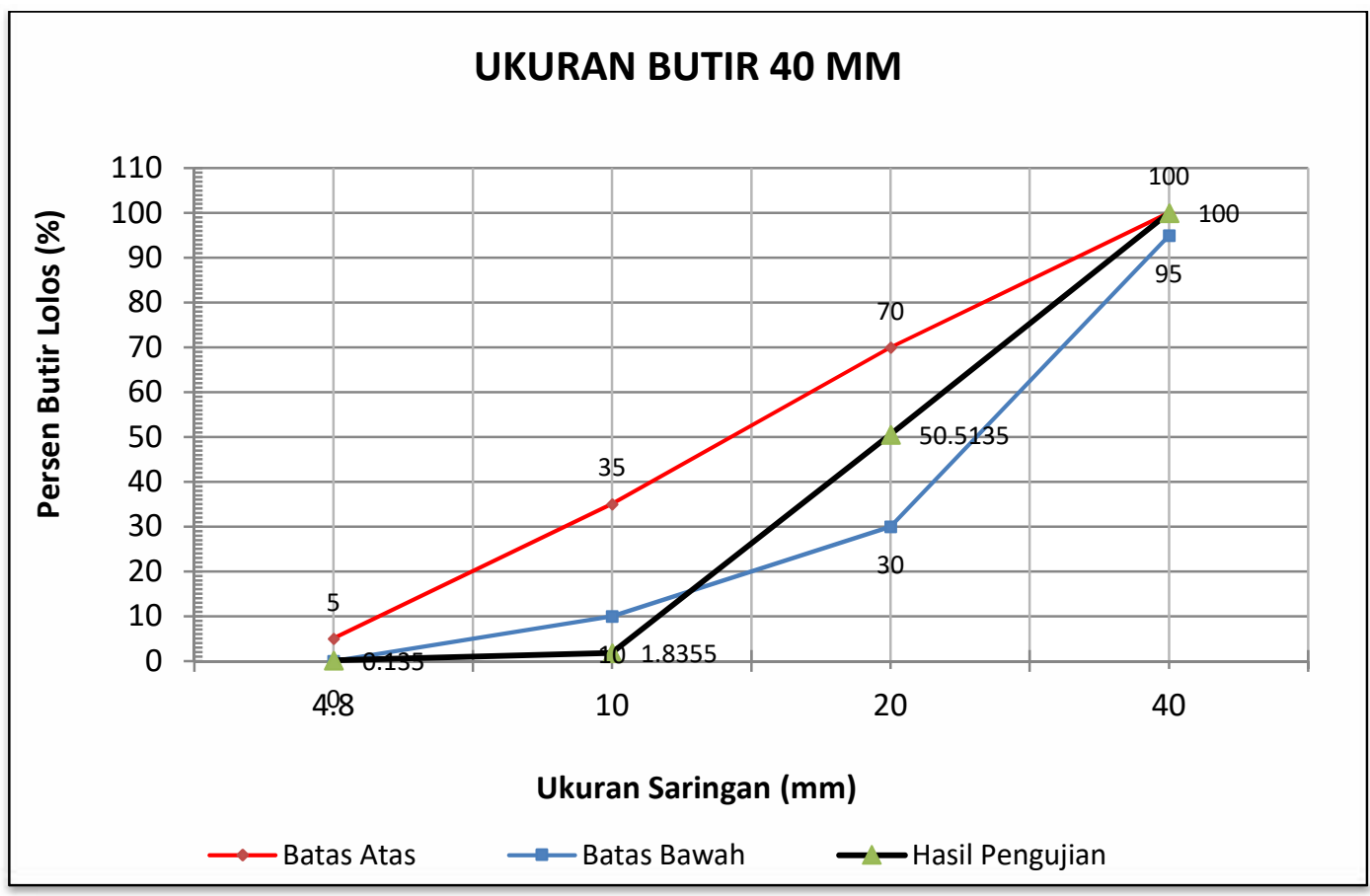

\section{Rancangan Campuran Beton dengan Mutu $20 \mathrm{Mpa}$}

Kekuatan tekan beton yang direncanakan adalah $20 \mathrm{Mpa}$ pada umur 28 hari.

Nilai slump rencana

Deviasi standar ( S ) diambil

Data-data material : Type semen yang akan dipakai adalah semen portlant type I Agregat : Type agregat halus = alamiah

Type agregat kasar

Ukuran butiran maksimun $=40 \mathrm{~mm}$

Persentase gabungan : - pasir $=35 \%$, batu pecah $=65 \%$

Berat jenis : pasir $=2,34$, Batu pecah $=2,79$

Kadar air : pasir $=11,57$, Batu pecah $=1,62$

Penyerapan air (absorption) : pasir $=2986,4 \%$, Batu pecah $=0,4 \%$

\section{Perhitungan faktor air semen (fas)}

- Mutu beton

$$
=20 \mathrm{Mpa}
$$

- Deviasi standar - Standar devisiasi $=$ (data tidak diketahui)

- Mementukan nilai margin : Nilai margin (M)

Target kekuatan rata-rata $(\boldsymbol{\sigma b m})=\boldsymbol{\sigma b m}+7 \mathrm{Mpa}$

$$
\begin{aligned}
& =20+7 \\
& =27 \mathrm{Mpa}
\end{aligned}
$$

Perkiraan kekuatan tekan beton pada umur 28 hari adalah $27 \mathrm{Mpa}$ $\mathrm{km} / \mathrm{cm} 2$. Nilai dari fas terhadap kekuatan tekan beton untuk umur 28 hari $=0,46$ (lihat lampiran grafik). 
Menentukan kadar air bebas (k.a.b)

Nilai slump

Ukuran butiran maksimun

$=60-120$

Type agregat

- agregat halus (alami) $=175$

- agregat kasar (batu pecah) $=205$

$$
\begin{aligned}
\text { Kadar air bebas } & \text { (k.a.b) }=2 / 3 \mathrm{wh}+1 / 3 \mathrm{wk} \\
\text { Wa }=\frac{2}{3} \mathrm{Wh}+\frac{1}{3} \mathrm{Wk} & =\frac{2}{3} \times 175+\frac{1}{3} \times 205 \\
= & 185 \mathrm{~kg} / \mathrm{cm}^{2} \\
& =\mathrm{k} \cdot \mathrm{ab} / \mathrm{b} / \mathrm{ss} \\
& =\frac{185}{0,+6 i} \\
& =402,17 \mathrm{~kg} / \mathrm{cm} 3
\end{aligned}
$$

\section{Menentukan berat total dan proporsi agregat halus dan kasar}

Dari grafik didapat : Pasir $=35 \%$, Batu pecah $=65 \%$

Berat jenis agregat gabungan $=(\%$ agregat halus $\mathrm{x}$ berat jenis agregat halus $)+(\%$ agregat kasar $x$ berat jenis agregat kasar $)$

Pasir $=2.34$

Batu pecah

Berat jenis gabungan

$$
\begin{aligned}
& =2,79 \\
& =(0,35 \times 2.34)+(0,65 \times 2.79) \\
& =0,819+1.81 \\
& =2,63
\end{aligned}
$$

Menentukan berat volume basah

Dari gambar diperoleh berat volume beton basah $=2373 \mathrm{~kg} / \mathrm{cm}^{2}$

Berat total agregat $=$ berat volume beton basah - kadar air bebas - kadar semen

Berat total agregat

$$
\begin{aligned}
& =2373-185-402,17 \\
& =1785,83 \mathrm{~kg} / \mathrm{cm}^{2}
\end{aligned}
$$

Kadar agregat halus dan agregat kasar $=\%$ agregat halus $\mathrm{x}$ berat total agregat

Agregat kasar

$=0,35 \times 1785,83$

$=625,04 \mathrm{~kg} / \mathrm{cm}^{2}$

Agregat halus

$=$ Berat agregat - Berat

$$
\begin{aligned}
& =1785,83-625,04 \\
& =1160,79 \mathrm{Kg} / \mathrm{m}^{3}
\end{aligned}
$$

\section{Berat komposisi}

Semen $(A)$

Air (B) $=185 \mathrm{Kg} / \mathrm{m}^{3}$

Agregat. Halus (C)

$=402,17 \mathrm{Kg} / \mathrm{m}^{3}$

Agregat. Kasar (D)

$=625,04 \mathrm{Kg} / \mathrm{m}^{3}$

$=1160,79 \mathrm{Kg} / \mathrm{m}^{3}$ 


\section{Koreksi kadar air pada rencana campuran Beton}

Dari hasil pemeriksaan karakteristik Agregat

Agregat halus

- Absorbsi

$$
=3.34 \%
$$

- Kadar air

$$
=11.57
$$

Agregat Kasar :

- Absorbsi

$$
=0,4 \%
$$

- Kadar air

$$
=1,62
$$

$$
\begin{aligned}
& \text { Perhitungan koreksi kadar air } \\
& \text { - Semen }(A)=402,17 \mathrm{Kg} / \mathrm{m}^{3} \\
& \text { - } \operatorname{Air}(\mathrm{B})=\mathrm{B}-(\mathrm{Ck}-\mathrm{Ca}) \times \frac{c}{100}-(\mathrm{Dk}-\mathrm{Da}) \times \frac{d}{100} \\
& =185-(11.57-3.34) \times \frac{625,04}{100}-(1,62-0,4) \times \frac{1160,79}{100} \\
& =185-51,44-14,16 \\
& =119,4 \mathrm{~kg} / \mathrm{m} 3 \\
& \text { - Agregat halus }=\mathrm{C}+(\mathrm{Ck}-\mathrm{Ca}) \times \frac{C}{100} \\
& \begin{array}{l}
=625,04+(11,57-3,34) \times \frac{625,04}{100} \\
=625,04-51,44 \\
=573,6 \mathrm{Kg} / \mathrm{m}^{3}
\end{array} \\
& \text { - Agregat kasar } \quad=\mathrm{D}+(\mathrm{Dk}-\mathrm{Da}) \times \frac{D}{100} \\
& =1160,79+(1,62-0,4) \frac{1160,79}{100} \\
& =1160,79+14,16 \\
& =1174,95 \mathrm{Kg} / \mathrm{m}^{3}
\end{aligned}
$$

\section{Bahan yang digunakan untuk percobaan laboratorium}

Berat material untuk 3 buah kubus adalah

volume 1 Kubus

$$
\begin{aligned}
& =\mathrm{s} \times \mathrm{s} \times \mathrm{s} \\
& =0,15 \times 0,15 \times 0,15 \\
& =0,003375 \mathrm{~m}^{3}
\end{aligned}
$$

\section{Proporsi Koreksi Campuran}

Komposisi campuran untuk mutu beton 20 Mpa sebagai berikut:

Air

Semen

Pasir

$$
=185 \mathrm{Kg}
$$

Batu Pecah

$$
\begin{aligned}
& =402,17 \mathrm{Kg} \\
= & 625,04 \mathrm{Kg}
\end{aligned}
$$$$
=1160,79 \mathrm{Kg}
$$

Maka proporsi campuran beton untuk 3 buah benda uji kubus sebagai berikut: 
Proporsi campuran untuk Beton Normal

$\begin{array}{lll}\text { Semen } & =402,17 \times 0,003375 \times 3 \times 1,2=4,89 \mathrm{~kg} \\ \text { Air } & =185 \times 0,003375 \times 3 \times 1,2 & =2,25 \mathrm{~kg} \\ \text { Pasir } & & =625,04 \times 0,003375 \times 3 \times 1,2=7,59 \mathrm{~kg} \\ \text { Batu pecah } & =1160,79 \times 0,003375 \times 3 \times 1,2=14,10 \mathrm{~kg}\end{array}$

\section{Proporsi campuran untuk abu sekam $10 \%$}

$\begin{array}{lll}\text { Semen } & =402,17 \times 0,003375 \times 3 \times 1,2=4,89 \mathrm{~kg} \\ \text { Air } & =185 \times 0,003375 \times 3 \times 1,2 & =2,25 \mathrm{~kg} \\ \text { Pasir } & =625,04 \times 0,003375 \times 3 \times 1,2=7,59 \mathrm{~kg} \\ \text { Batu pecah } & =1160,79 \times 0,003375 \times 3 \times 1,2=14,10 \mathrm{~kg} \\ \text { Abu sekam } 10 \% & =10 \% \times 4,89 & =0,489 \mathrm{~kg}\end{array}$

\section{Hasil Perhitungan Kuat Tekan}

Berdasarkan hasil pengujian kuat tekan beton dari benda uji kubus, maka kuat tekan beton dapat dihitung sebagai berikut ( di ambil contoh N281, N282, N283, AS281, AS282, AS283 ) :

\section{Beton Normal,}

Luas kubus $(\mathrm{A}) \quad=225 \mathrm{~cm}^{2}$

Pmax N281 $=4803,5 \mathrm{~kg}$

Kuat Tekan $\quad=\frac{\mathrm{r}}{\mathrm{A}}=\frac{4803,5}{225}=21.3 \mathrm{Mpa}$

Luas kubus $(A) \quad=225 \mathrm{~cm}^{2}$

Pmax N282 $=4847,2 \mathrm{~kg}$

Kuat Tekan $\quad=\frac{\mathrm{r}}{\mathrm{A}}=\frac{4847,2}{225}=21,5 \mathrm{Mpa}$

Luas kubus $(A) \quad=225 \mathrm{~cm}^{2}$

$$
=\frac{\mathrm{r}}{\mathrm{A}}=\frac{4847,2}{225}=21,5 \mathrm{Mpa}
$$

Pmax N283

$$
\begin{aligned}
& =4541,5 \mathrm{~kg} \\
& =\frac{\mathrm{P}}{\mathrm{A}}=\frac{4541.5}{225}=20,2 \mathrm{Mpa}
\end{aligned}
$$

Kuat Tekan

Untuk perhitungan kuat tekan beton pada umur 3, 7, dan 14 hari sama dengan perhitungan beton pada umur 28 hari. Keseluruhan hasil kuat tekan beton normal dapat dilihat pada Tabel 1 . 
Tabel 1. Hasil Uji Kuat Tekan Beton Normal

\begin{tabular}{|c|c|c|c|c|c|c|c|c|}
\hline No. & $\begin{array}{l}\text { Umur } \\
\text { beton }\end{array}$ & $\begin{array}{c}\text { Kuat } \\
\text { Tekan } \\
\text { Rencana }\end{array}$ & Berat & $\begin{array}{c}\text { Luas } \\
\text { kubus }\end{array}$ & Beban & Beban & $\begin{array}{c}\text { Kuat } \\
\text { Tekan }\end{array}$ & $\begin{array}{c}\text { Hasil } \\
\text { konversi } \\
\text { Kuat Tekan } \\
\text { beton untuk } \\
\text { umur } 28 \text { hari }\end{array}$ \\
\hline & Hari & (Mpa) & (kg) & $\left(\mathrm{cm}^{2}\right)$ & (kN) & (kg) & (Mpa) & (Mpa) \\
\hline $\mathrm{N}_{1}$ & \multirow{3}{*}{3} & 20 & 8,095 & 225 & 225 & 1965,7 & 8,7 & 21,8 \\
\hline $\mathrm{N}_{3}$ & & 20 & 8,000 & 225 & 210 & 1834,6 & 8,2 & 20,5 \\
\hline $\mathrm{N}_{3}$ & & 20 & 8,230 & 225 & 220 & 1921,4 & 8,5 & 21,3 \\
\hline $\mathrm{N} 7_{1}$ & \multirow{3}{*}{7} & 20 & 7,730 & 225 & 490 & 4279,5 & 19 & 29,2 \\
\hline $\mathrm{N}_{2}$ & & 20 & 8,080 & 225 & 480 & 4192,4 & 18,6 & 28,6 \\
\hline $\mathrm{N}_{3}$ & & 20 & 7,780 & 225 & 370 & 3231,4 & 14,4 & 22,1 \\
\hline $\mathrm{N} 14_{1}$ & \multirow{3}{*}{14} & 20 & 7,945 & 225 & 500 & 4366,8 & 19,4 & 22,0 \\
\hline $\mathrm{N}_{14}{ }_{2}$ & & 20 & 7,890 & 225 & 470 & 4104,8 & 18,2 & 20,7 \\
\hline $\mathrm{N}_{14}$ & & 20 & 7,905 & 225 & 480 & 4192,4 & 18,6 & 21,1 \\
\hline $\mathrm{N} 28_{1}$ & \multirow{3}{*}{28} & 20 & 7,790 & 225 & 550 & 4803,5 & 21,3 & 21,3 \\
\hline $\mathrm{N} 28_{2}$ & & 20 & 7,320 & 225 & 555 & 4847,2 & 21,5 & 21,5 \\
\hline $\mathrm{N} 28_{3}$ & & 20 & 7,700 & 225 & 520 & 4541,5 & 20,2 & 20,2 \\
\hline
\end{tabular}

Dari tabel hasil kuat tekan beton terlihat kuat tekan terendah beton dari tiga benda uji pada umur 3 hari sebesar $8,2 \mathrm{Mpa}, 7$ hari sebesar 14,4 Mpa, 14 hari sebesar 18,2 Mpa dan 28 hari sebasar 20,2 Mpa. Kuat tekan beton pada umur 28 hari ternyata lebih besar dari kuat tekan rencana, dimana kuat tekan rencana $=20 \mathrm{Mpa}$ sedangkan kuat tekan beton dari hasil pengujian lab = 20,2 Mpa.

\section{Beton yang menggunakan Abu Sekam $10 \%$}

$$
\begin{array}{lll}
\text { Luas kubus (A) } & =225 \mathrm{~cm}^{2} \\
\text { Pmax AS281 } & =4978,7 \mathrm{~kg} \\
\text { Kuat Tekan } & =\frac{\mathrm{r}}{\mathrm{A}}=\frac{4978,7}{225}=22,1 \mathrm{Mpa}
\end{array}
$$

Luas kubus $(A) \quad=225 \mathrm{~cm}^{2}$

$$
\begin{array}{ll}
\text { Pmax AS282 } & =4847,6 \mathrm{~kg} \\
\text { Kuat Tekan } & =\frac{\mathrm{P}}{\mathrm{A}}=\frac{4847,6}{225}=21,5 \mathrm{Mpa}
\end{array}
$$

Luas kubus $(A) \quad=225 \mathrm{~cm}^{2}$

Pmax AS283 $=4847,6 \mathrm{~kg}$

Kuat Tekan

$$
=\frac{\mathrm{P}}{\mathrm{A}}=\frac{4847,6}{225}=21,5 \mathrm{Mpa}
$$


Untuk perhitungan kuat tekan beton pada umur 3, 7, dan 14 hari sama dengan perhitungan beton pada umur 28 hari. Keseluruhan hasil kuat tekan beton yang menggunakan agregat kasar batu pecah dapat dilihat pada Tabel 2.

Tabel 2. Hasil Perhitungan Kuat Tekan Beton Menggunakan Abu Sekam Padi $10 \%$

\begin{tabular}{|c|c|c|c|c|c|c|c|c|}
\hline No. & $\begin{array}{c}\text { Umu } \\
r\end{array}$ & $\begin{array}{c}\text { Kuat } \\
\text { Tekan } \\
\text { Rencan } \\
\text { a } \\
\end{array}$ & Berat & $\begin{array}{c}\text { Luas } \\
\text { kubus }\end{array}$ & Beban & Beban & Kuat Tekan & $\begin{array}{c}\text { Hasil } \\
\text { konversi Kuat } \\
\text { Tekan beton } \\
\text { untuk umur } \\
28 \text { hari } \\
\end{array}$ \\
\hline & Hari & (Mpa) & (kg) & $\left(\mathrm{cm}^{2}\right)$ & $(\mathrm{kN})$ & (kg) & (Mpa) & (Mpa) \\
\hline $\mathrm{AS}_{1}$ & \multirow{3}{*}{3} & 20 & 7,765 & 225 & 300 & 2620,6 & 11,6 & 29,0 \\
\hline $\mathrm{AS}_{2}$ & & 20 & 7,740 & 225 & 310 & 2707,4 & 12,0 & 30,0 \\
\hline $\mathrm{AS}_{3}$ & & 20 & 7,975 & 225 & 325 & 2838,4 & 12,6 & 31,5 \\
\hline $\mathrm{AS7}_{1}$ & \multirow{3}{*}{7} & 20 & 7,7920 & 225 & 375 & 3275,1 & 14,5 & 22,3 \\
\hline $\mathrm{AS7}_{2}$ & & 20 & 7,730 & 225 & 390 & 3406,1 & 15,1 & 23,2 \\
\hline $\mathrm{AS7}_{3}$ & & 20 & 7,855 & 225 & 420 & 3668,2 & 16,3 & 25,1 \\
\hline $\begin{array}{c}\text { AS14 } \\
1\end{array}$ & \multirow{3}{*}{14} & 20 & 7,810 & 225 & 465 & 4061,4 & 18,0 & 20,4 \\
\hline $\begin{array}{c}\text { AS14 } \\
2 \\
\end{array}$ & & 20 & 7,805 & 225 & 490 & 4279,8 & 19,0 & 21,6 \\
\hline $\begin{array}{c}\text { AS14 } \\
3 \\
\end{array}$ & & 20 & 8,030 & 225 & 580 & 4192,4 & 18,6 & 21,1 \\
\hline $\begin{array}{c}\text { AS28 } \\
1 \\
\end{array}$ & \multirow{3}{*}{28} & 20 & 8,280 & 225 & 570 & 4978,7 & 22,1 & 22,1 \\
\hline $\begin{array}{c}\text { AS28 } \\
2 \\
\end{array}$ & & 20 & 8,340 & 225 & 575 & 5021,8 & 22,3 & 22,3 \\
\hline $\begin{array}{c}\mathrm{AS} 28 \\
3\end{array}$ & & 20 & 8,410 & 225 & 555 & 4847,6 & 21,5 & 21,5 \\
\hline
\end{tabular}

Dari tabel hasil kuat tekan beton terlihat kuat tekan terendah dari tiga benda uji pada umur 3 hari sebesar 11,6 Mpa, 7 hari sebesar 14,5, 14 hari sebesar 18,0 Mpa dan 28 hari sebasar 21,5 Mpa. Kuat tekan beton pada umur 28 hari ternyata lebih besar dari kuat tekan rencana, dimana kuat tekan rencana $=20 \mathrm{Mpa}$ sedangkan kuat tekan beton dari hasil pengujian $\mathrm{lab}=21,5 \mathrm{Mpa}$.

Persentase kuat tekan beton normal dengan beton yang menggunakan abu sekam padi $10 \%$ pada umur $3,7,14$, dan 28 hari sebagai berikut :

Umur 3 hari $=\frac{11,6-8,2}{19,8} \times 100 \%=17,2 \%$ 
Umur 7 hari $=\frac{14,5-14,4}{28,9} \times 100 \%=0,3 \%$

Umur 14 hari $=\frac{18,0-18,2}{36,2} \times 100 \%=-0,5 \%$

Umur 28 hari $=\frac{21,5-20,2}{41,7} \times 100 \%=3,1 \%$

Untuk melihat perbandingan dari hasil pengujian kuat tekan beton normal dengan beton yang menggunakan abu sekam padi dapat dilihat pada Grafik 6.

Grafik 6. Hasil Perbandingan Kuat Tekan Beton Normal dengan Beton yang Menggunakan Abu Sekam Padi

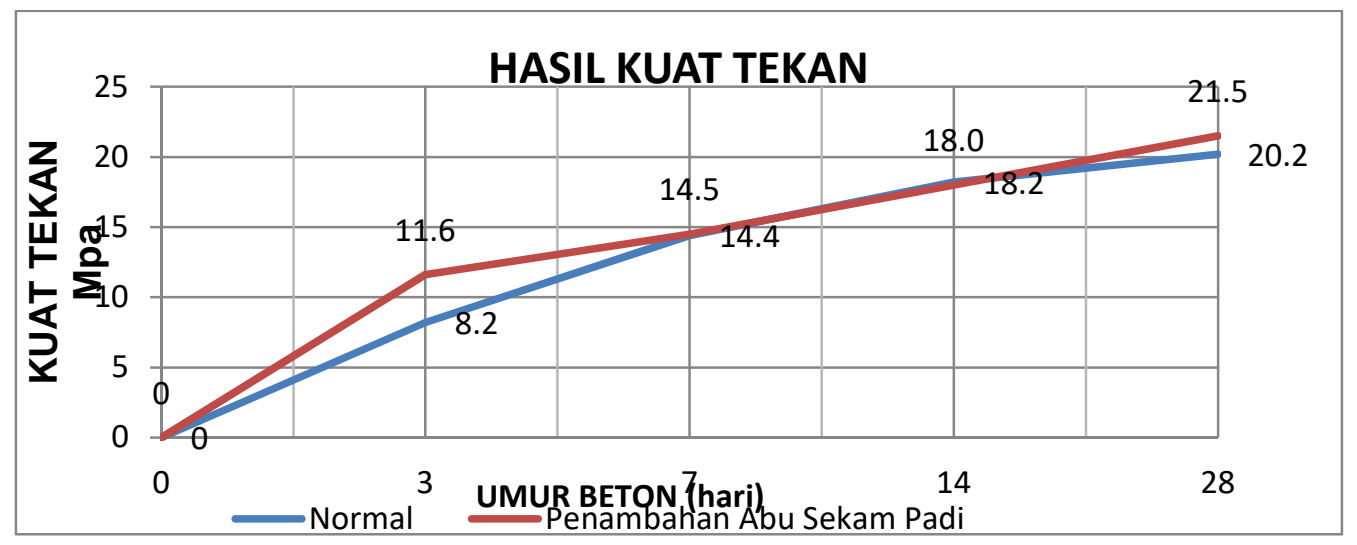

Dari grafik dapat diketahui peningkatan kuat tekan beton baik beton normal maupun beton yang menggunakan abu sekam padi, yaitu pada hari ke- 3 kuat tekan beton normal 8,2 Mpa sedangkan kuat tekan yang menggunakan abu sekam padi $10 \%$ sebesar $11,6 \mathrm{Mpa}$ meningkat sebesar 17,2\%. Pada hari ke- 7 kuat tekan beton normal 14,4 Mpa sedangkan kuat tekan benda uji yang menggunakan abu sekam padi 10 $\%$ sebesar 14,5 Mpa meningkat sebesar 0,3\%. Pada hari ke- 14 kuat tekan beton normal sebesar 18,2 Mpa sedangkan kuat tekan benda uji yang menggunakan abu sekam padi $10 \%$ sebesar 18,0 Mpa menurun sebesar $0,5 \%$ dari kekuatan beton normal. Pada hari ke- 28 kuat tekan beton normal sebesar 20,2 Mpa sedangkan kuat tekan yang menggunakan abu sekam padi sebesar 21,5 Mpa meningkat sebesar $3,1 \%$ dari beton normal. 


\section{KESIMPULAN DAN SARAN}

\section{Kesimpulan}

1. Setelah melakukan pengujian terhadap agregat halus asal Tapparan dan agregat kasar (batu pecah) asal PT. Sabar Jaya, maka hasil penelitian menunjukkan bahwa kedua agregat tersebut memenuhi spesifikasi yang disyaratkan oleh American Society for Testing and Materials (ASTM). Yaitu mempunyai sifat yang baik seperti yang terlihat pada tabel 4.1. dan tabel 4.2.

2. Hasil pengujian kuat tekan beton normal dan beton dengan penambahan abu sekam padi pada umur 28 hari mengalami peningkatan yaitu sebesar $3,1 \%$ dari beton normal.

3. Penambahan abu sekam sebanyak $10 \%$ meningkatkan kuat tekan beton pada umur 28 hari yaitu 21,5 Mpa. Hal ini disebabkan karena rongga - rongga udara di dalam beton telah terisi dengan abu sekam padi.

4. Dari hasil penelitian dapat disimpulkan bahwa abu sekam padi dapat digunakan sebagai bahan pengisi (Filler) dalam pembuatan beton karena dapat meningkatkan kuat tekan beton.

\section{Saran}

Setelah melakukan penelitian tentang penambahan abu sekam padi dalam pembuatan beton, maka penulis memberikan saran sebagai berikut

1. Untuk mendapatkan mutu beton yang baik maka dalam pelaksanaan penelitian benar - benar memperhatikan spesifikasi setiap pengujian dengan baik dan teliti.

2. Perlu dilakukan penelitian lebih lanjut untuk memperoleh kenaikan kekuatan beton dengan memperhatikan komposisi penambahan abu sekam padi terhadap campuran beton.

3. Perlu memperhatikan metode pengerjaan beton yang baik dalam penambahan abu sekam padi dalam adukan agar penyebaran abu sekam padi lebih merata.

\section{DAFTAR PUSTAKA}

American Society for Testing and Material (ASTM), C-33-93 Section 4 Contruction Volume 04.02, "concrete and aggregates", 1997

Anonymus, "Tata Cara Pembuatan Rencana Campuran Beton Normal, SK

SNI T-15-1990-3", Departemen Pekerjaan Umum. 
Antoni, Nugraha Paul,. "Teknologi Beton, Dari Meterial, Pembuatan ke Beton Kinerja Tinggi”, 2007.

http://www. Abu Sekam Padi.com.

Jack C. McCorma. 1994. "Desain Beton Bertulang, Edisi Kelima, Jilid I.

Mulyono, Sri. 2001. "Pengaruh Penambahan Abu Sekam Padi Terhadap

Mutu Beton". Sekolah Tinggi Teknologi Nasional Yogyakarta.

Mulyono Tri. Ir, "Teknologi Beton”, Jakarta 2004.

SNI 03-1974-1990, "Metode Pengujian Kuat Tekan”. Pusat Penelitian dan Pengembangan Prasarana Transportasi, Balitbang Departemen Kimpraswil, Bandung.

Tjokrodimulyo, 2007. “Teknologi Beton”. Teknik Sipil Universitas Gadjah Mad, Yogyakarta 